\title{
PERUBAHAN IKLIM DAN KAITANNYA DENGAN PENYEBARAN KOMODITAS TANAMAN PANGAN DAN HOLTIKULTURA DI KABUPATEN PASAMAN BARAT
}

\author{
Oleh: \\ Ratna Wilis \\ Dosen Jurusan Geografi FIS Universitas Negeri Padang \\ Email: ratna_geounp@yahoo.com
}

\begin{abstract}
Abstrak
Peningkatan suhu udara juga akan meningkatkan serangan hama dan penyakit, baik pada tanaman maupun bintang ternak. Sub sektor tanaman pangan dan hortikultura merupakan salah satu sub sektor unggulan daerah. Tujuan khusus dari penelitian ini adalah menganalisis perubahan iklim dan kaitannya dengan penyebaran komoditas tanaman pangan dan holtikultura di Kabupaten Pasaman Barat. Metode penelitian ini termasuk research dengan menggunakan data iklim (terutama data curah hujan), baik data observasi maupun data reanalisis serta data produksi tanaman pangan dan holtikultura untuk 5 tahun (2011-2015). data yang berhubungan dangan iklim diambil dari beberapa kantor BMKG, dan data penduduk bisa dari BPS Kota Padang, Pengolahan data dengan software RClimDex, yakni Expert Team for Climate Change Detection and Indices (ETCCDMI) untuk mendeteksi dan monitoring perubahan iklim dengan fokus utama pada kejadian-kejadian iklim ekstrim. Selama periode tahun 2000-2015, curah hujan di wilayah pesisir pantai mempunyai variasi tahunan yang relatif kecil dibandingkan dengan curah hujan tahunan di wilayah daratan pedalaman Pasaman Barat. Fenomena global ENSO (El Nino dan La Nina) tidak secara signifikan mempengaruhi variabilitas curah hujan bulanan di wilayah Kab. Pasaman Barat, baik untuk di wilayah pesisir pantai maupun wilayah daratan pedalamannya. Kecamatan yang tertinggi untuk produktivitas tanaman pangan adalah Kecamatan Talamau, Peringkat sedang pada Kecamatan Ranah Patahan, Lembah Melintang, Luhak Nan Duo, dan Kinali, sedangkan peringkat rendah diraih oleh Kecamatan Sungai Beremas, Sungai Aua, Gunung Tuleh, Pasaman, Sasak, dan Koto Balingka. Kecamatan yang tertinggi untuk produktivitas tanaman buahnya adalah Kecamatan Sungai Beremas, Gunung Tuleh, dan Talamau. Peringkat sedang pada Kecamatan Ranah Patahan, Koto Balingka, Sungai Aua, Lembah Melintang, Pasaman, Luhak Nan Duo, dan Sasak. Daerah yang paling rendah adalah Kecamatan Kinali.
\end{abstract}

\section{Kata Kunci : Perubahan iklim, Tanaman Pangan dan Holtikultura}

\section{PENDAHULUAN}

Meningkatnya pertambahan penduduk di Indonesia, menjadi suatu tantangan bagi pemerintah dalam penyediaan pangan untuk memenuhi kebutuhan masyarakat di masa yang akan datang. Keberadaan petani padi sangat dibutuhkan seluruh masyarakat karena merekalah produsen bahan pangan yang kita perlukan sehari-hari.
Dengan jumlah penduduk sekitar 237 juta (tahun 2010) dan laju pertumbuhan 1,3\% per tahun (tahun 2005-2010), 1,18\% per tahun (tahun 2011-2015), dan menjadi 0,82\% per tahun (tahun 2025-2030), maka jika konsumsi per kapita tetap (139kg/kapita/tahun) maka tahun 2030 nanti kita memerlukan 59 ton beras. Sedangkan pada tahun 2008, kita baru 
mampu memproduksi sekitar 40 juta ton beras (Prabowo, 2007). Untuk memenuhi kebutuhan beras tersebut tentu memerlukan upaya-upaya ekstra keras mengingat konversi lahan pertanian terutama sawah menjadi lahan nonpertanian masih terus terjadi, sehingga akan menambah kesulitan dalam pencapaian pemenuhan kebutuhan beras.

Pembangunan Pertanian di Kabupaten Pasaman Barat adalah yang sangat penting artinya bagi peningkatan kesejahteraan masyarakat secara umum. Hal ini disebabkan karena mayoritas penduduk adalah petani atau orang yang mengelola usaha pertanian. Pembangunan Pertanian secara khusus untuk periode 2011-2015 di Kabupaten Pasaman Barat lebih dititik beratkan kepada peningkatan sumber daya manusia dan pengadaan sarana dan prasarana pertanian serta revitalisasi. Hal ini sesuai dengan situasi dan kondisi Kabupaten Pasaman Barat selaku daerah yang baru dimekarkan.

Sektor pertanian merupakan salah satu sektor dominan dalam menopang perekonomian Kabupaten Tanah Datar. Hal ini bisa saja terjadi karena $70 \%$ penduduknya bergerak pada bidang pertanian, baik pertanian tanaman pangan, perkebunan, perikanan maupun peternakan. Guna melaksanakan tugas tersebut, maka Dinas Pertanian Tanaman Pangan dan Hortikultura wajib menyusun Rencana Kinerja guna pengembangan sektor pertanian terutama sub sektor Tanaman Pangan dan Hortikultura. Sasaran Strategis Pembangunan Pertanian 2015 -2019, kementerian pertanian mencanangkan 4 sasaran strategis, yaitu : (1). Peningkatan Ketahanan Pangan, (2) Pengembangan Ekspor dan Substitusi Impor Produk Pertanian, (3).
Pengembangan Penyediaan bahan baku bioindustri dan bioenergi,

Pengembangan Infrastruktur Pertanian.

Jenis komoditi unggulan tanaman pangan di kabupaten ini adalah padi, jagung, kacang tanah, ubi kayu, ubi jalar, kedele serta kacang tanah. Sedangkan komoditi hortikultura adalah cabe, bawang daun, tomat, wortel, terung, bawang merah, kubis, buncis, sawi dan kentang, komoditi hortikultura lainnya adalah buahbuahan diantaranya adalah sawo, alpokat, durian, rambutan dan pisang..

Di tengah resiko-resiko yang tidak ringan yang harus dihadapi petani, muncul fenomena perubahan iklim yang dampaknya juga cukup besar bagi para petani terutama petani padi. Perubahan iklim global menyebabkan musim kemarau panjang atau musim hujan yang berlebihan akan curah hujan dengan intensitas hujan yang tinggi.

Kenaikan suhu udara akan berdampak pada penurunan produktivitas tanaman terutama pada tanaman semusim. Kondisi ini juga berpengaruh terhadap produktifitas ternak. Disamping itu peningkatan suhu udara juga akan meningkatkan serangan hama dan penyakit, baik pada tanaman maupun bintang ternak. Berubahnya pola curah hujan dan peningkatan intensitas kejadian iklim ekstrim menyebabkan kekeringan atau banjir yang akan berpotensi besar untuk menurunkan produktivitas bahkan menggagalkan panen. Kondisi ini juga dapat menyebabkan ternak stress dan berakibat pada kemerosotan produksi (Guntoro, 2011). Selain itu kondisi iklim eksrim juga menyebabkan hujan dengan intensitas yang tinggi yang disertai dengan angin kencang (puting beliung) dan badai. Hal ini dapat menyebabkan kemerosotan 
produksi pada tanaman tahunan (tanaman pohon) akibat banyaknya cabang atau ranting yang patah dan penyerbukan yang gagal karena bunga yang gugur. Di pihak lain kegiatan para nelayan untuk menangkap ikan menjadi terbatas akibat gelombang yang yang tinggi dan badai.

Fenomena perubahan iklim dengan segala dampaknya, jangan hanya dilihat dari sisi negatif semata. Karena dibalik fenomena tersebut juga memunculkan berbagai peluang dan tantangan terutama bagi para petani Indonesia untuk dapat menangkap peluang tersebut. Beberapa hal yang perlu kita jadikan peluang sekaligus tantangan untuk kita penuhi antara lain : (1) peningkatan produksi pangan dan pakan, (2) produksi energi alternatif khususnya bioenergi, dan (3) optimalisasi pemanfaatan sumber daya lokal. Pada saat sekarang belum ada informasi tentang pengaruh perubahan iklim yang terjadi dan pernyebaran komuditas tanaman pangan dan holtikultura di setiap kecamatan yang ada di kabupaten Pasaman Barat. Penyebaran komuditas ini perlu dilakukan dengan pertimbangan bisa mengetahui apa komuditas unggulan tanaman pangan dan holtikultura untuk setiap kecamatan yang ada disini.

\section{TINJAUAN PUSTAKA}

\section{Pemanasan Global}

Pemanasan global terjadi sebagai efek dari emisi GRK (Gas Rumah Kaca), seperti metana, nitrat oksida, hidrofluorokarbon, perfluorokarbon, dan heksafluorida. Belum lagi pabrik dan kendaraan yang berbahan bakar minyak menghasilkan gas buang berupa karbondioksida $\left(\mathrm{CO}_{2}\right)$. Semakin deras perkembangan industri dan transportasi, maka semakin tinggi pula konsentrasi $\mathrm{CO}_{2}$ dan gas rumah kaca di atmosfir (Guntoro, 2011).

Pemanasan global telah menyebabkan terjadinya pergesaran terhadap pola iklim secara global. Beberapa hal yang dapat dijadikan bukti bahawa telah terjadi perubahan iklim diantaranya adalah semakin seringnya terjadi badai tropis (siklon tropis) di daerah tertentu yang menyebabkan banjir atau semakin keringnya suatu daerah karena curah hujan semakin langka, atau kombinasi keduanya, menyebabkan kondisi yang ekstrim karena pada saat tertentu terjadi banjir dan pada saat yang lain akan terjadi kekeringan. Perubahan iklim yang lain juga dapat dilihat dari terjadinya perubahan pola musim, frekuensi dan/atau intensitas curah hujan, terjadinya cuaca ekstrim, gelombang panas. Selain itu suhu udara rata-rata harian yang semakin meninggi dan semakin naiknya level permukaan air laut di beberapa lokasi di bumi merupakan bukti adanya perubahan iklim yang paling mudah disaksikan.

Perubahan iklim adalah perubahan dari keadaan iklim (seperti: suhu, curah hujan, angin, dan variabel cuaca lainnya), baik itu nilai rata-ratanya dan atau variabilitasnya yang berlangsung lama pada periode berikutnya, baik pada periode decadal atau yang lebih panjang. Dari laporan IPCC tahun 2007 juga dapat diketahui bahwa proyeksi temperatur udara permukaan bumi di masa depan akan meningkat sekurang-kurangnya $\quad 0,2^{\circ} \mathrm{C} \quad$ setiap dekadenya. Beberapa skenario bahkan memberikan hasil yang jauh lebih tinggi dari nilai tersebut. Hal ini mengindikasikan bahwa terjadinya pemanasan global dan perubahan iklim merupakan tantangan besar yang terus dihadapi di masa yang akan datang. (AR4-IPCC, 2007). 
Dampak dari perubahan iklim secara radikal antara lain adanya perubahan pola curah hujan dan pergeseran musim, semakin sering terjadi badai dan angin kencang, serta es di kutub mencair dan menyebabkan kenaikan permukaan air laut, sehingga didasawarsa ketiga abad 21 ini diperkirakan sebagian wilayah beberapa kota pesisir dan pulau kecil akan tenggelam (Guntoro, 2011). Perubahan iklim yang terjadi sangat membahayakan bagi kehidupan di muka bumi. Semakin diperlukan suatu kajian untuk meneliti dan mengurangi faktor-faktor sebagai penyebab terjadinya pemanasan secara global.

\section{Peran Strategis Subsektor Pangan dan Hortikultura}

Dalam konteks pembangunan nasional pada waktu lalu, sektor pertanian termasuk didalamnya subsektor TPH dipandang sebagai pendukung bukan sebagai mesin penggerak perekonomian. Sebagai sektor pendukung maka sektor pertanian diposisikan sebagai (a) pemasok bahan kebutuhan pangan dan bahan baku industri berharga murall; (b) pengendali stabilitas harga, dan (c) pemasok tenaga kerja murah.

Subsektor tanaman pangan dan hortikultura merupakan penghasil bahan makanan pokok. Sementara itu, ketahanan pangan merupakan prasyarat utama bagi tercapainya ketahanan ekonomi maupun ketahanan politik. Dalam kondisi perekonomian global maupun domestik yang tidak stabil maka ketahanan pangan yang paling mantap ialah melalui pencapaian swasembada bahkan surplus merupakan upaya untuk memantapkan ketahanan nasional dalam menghadapi tantangan global. Subsektor tanaman pangan dan hortikultura tetap menempati posisi penting dalam perekonomian nasional. Lebih daripada itu, subsektor ini memiliki keunggulan khas dari sektorsektor lain dalam perekonomian : (a) produksi tanaman pangan dan hortikultura berbasis pada sumberdaya domestik sehingga kandungan impornya rendah dan relatif lebih tangguh menghadapi gejolak perekonomian eksternal,dan (b) produksi tanaman pangan dan hortikultura berbasis pada sumberdaya alam sehingga relatif lebih tangguh menghadapi gejolak ekonomi makro domestik, seperti gejolak moneter, nitai tukar maupun fiskal.

Dengan demikian, upaya mempertahankan dan meningkatkan peranan subsektor tanaman pangan dan hortikultura dalam perekonomian nasional merupakan cara yang efektif untuk meningkatkan ketahanan ekonomi. Kehilangan hasil ini perlu ditekan dalam upaya peningkatan produksi melalui perbaikan teknologi panen dan pasca panen. d) Sebagian besar produk pertanian masih berkualitas rendah yang memperlemah daya saing produk baik di pasar dalam negeri ataupun sektor. Pembinaan bagi peningkatan kualitas dan standardisasi produk pertanian dapat dipandang sebagai kegiatan yang dapat meningkatakan nilai tambah daya saing produk. e) Penggunaan produk tanaman pangan dan hortikultura semakin beragam, tidak saja untuk makanan langsung dan ekspor tetapi juga bahan baku industri dan pakan ternak.

Diversifikasi penggunaan produk mendorong peningkatan permintaan terhadap produk-produk olahan pertanian yang dapat meningkatkan nilai tambah dan perputaran roda perekonomian nasional. (f) Insentif investasi dalam kegiatan agribisnis belum mencukupi, terutama 
yang berkaitan dengan kebijakan makro ekonomi dan besarnya resiko dibidang agribisnis. Apabila diberikan kompensasi atas resiko yang berkaitan dengan sifatsifat alamiah produk pertanian yang mempunyai tingkat ketergantungan tinggi terhadap alam, musim, volumius dan mudah rusak; maka minat investasi dibidang pertanian dapat meningkat. (g) Pemanfaatan teknologi padat modal dan mekanisme pertanian sampai saat ini belum sepenuhnya dilakukan karena adanya keinginan agar subsektor tanaman pangan dan hortikultura atau sektor pertanian pada umumnya menyediakan lapangan kerja yang banyak. Hal ini menyebabkan produktivitas dan pertumbuhan sektor pertanian rendah. Kebijakan ini perlu dirubah agar mampu menjadi sektor andalan dan penggerak pembangunan

\section{Arah Pembangunan Subsektor Pangan dan Hortikultura}

Program pembangunan subsektor tanaman pangan dan hortikultura adalah sebagai berikut :

1. Memposisikan kembali sektor pertanian sebagai sektor andalan dan mesin penggerak pembangunan ekonomi nasional untuk mendukung tumbuh kembangnya sektor ekonomi lainnya.

2. Menempatkan keberpihakan pasta petani untuk memberdayakan masyarakat petani sebagai subyek pembangunan dalam rangka meningkatkan kesejahteraan masyarakat dan ketahanan nasional.

3. Mengoperasionalkan sistem agribisnis sebagai suatu pendekatan pembangunan agar terwujud keterpaduan dalam pembangunan dan berkembangnya perekonomian wilayah.
Tujuan Pembangunan Tanaman Pangan dan Hortikultura adalah sebagai berikut :

1. Meningkatkan pendapatan dan taraf hidup petani nelayan.

2. Meningkatkan ketahanan pangan nasional.

3. Menghasilkan produk-produk pertanian yang berdaya saing tinggi untuk mengisi pasar domestik dan ekspor.

4. Meningkatkan lapangan kerja dengan produktivitas tinggi dan kesempatan berusaha yang efisien dibidang agribisnis.

5. Meningkatkan kemandirian petaninelayan dan pemberdayaan lembagaan serta prasarana pertanian.

Ketahanan horlikultura dicirikan oleh ketersediaan komoditas holtikultura yang mencukupi serta manajemen produksi yang tidak rentan terhadap perubahanperubahan kondisi alam yang tidak bersahabat maupun perubahan ekonomi. tercakup di dalamnya kemampuan untuk memenuhi secara konsisten dan kontinyu kebutuhan konsumsi masyarakat Indonesia dan pasokan bahan baku industri serta kebutuhan pasar regional dan internasional. Disamping jumlah pasokan pasar-pasar tersebut juga menetapkan standar mutu tertentu. Oleh karena ilu untuk menghasilkan produk hortikultura dengan jumlah dan mutu sesuai permintaan pasar, pembangunan sub sektor hortikultura ditempuh melalui pengembangan sentra-sentra agribisnis hortikultura.

\section{METODE PENELITIAN}

Jenis penelitian adalah deskriptif kuantitatif. Penelitian ini secara khusus bertujuan untuk mendeteksi terjadinya perubahan iklim yang terjadi di wilayah 
Pasaman Barat dan menganalisis perubahan iklim dan kaitannya dengan penyebaran komoditas pertanian di Kabupaten Pasaman Barat .

\section{Data Penelitian}

Untuk mendeteksi terjadinya perubahan iklim di wilayah Pasaman Barat diperlukan data unsur-unsur klimatologi terutama curah hujan, suhu udara maksimum, suhu udara setidaknya mempunyai kontinuitas data selama 30 tahun.

\section{Pengolahan data}

- CDO

Climate Data Operator (CDO) merupakan software yang dikembangkan oleh Uwe Schulzweida dan Luis Kornblueh dari Max Plank Institute for Meteorology, Jerman pada Tahun 2009 (CDO Versi 1.4.1). Dalam penelitian ini software $\mathrm{CDO}$ digunakan untuk memanipulasi data ERA-Interim yang berformat multi dimensi menjadi data numerik.

\section{- GrADS}

Grid Analysis and Display System (GrADS), merupakan software yang dikembangkan oleh Brian Doty pada
Tahun 1995. Dalam penelitian ini software GrADS digunakan untuk mengekstrak data ERA-Interim menjadi data titik-titik pada koordinat-koordinat yang telah ditentukan.

\section{HASIL DAN PEMBAHASAN \\ Curah Hujan}

\section{Distribusi Spasial Curah Hujan di Kab. Pasaman Barat}

Pada Gambar 2 terlihat bahwa curah hujan tahunan di Kab. Pasaman barat berkisar antara 3500-4500 $\mathrm{mm} /$ tahun. Curah hujan antara 3500-4000 mm/tahun terjadi di Kec. Sungai Baremas, Sungai Aur, Sasak Ranah Pesisir, Kinali, Luhak Nan Duo, Ranah Batahan, Koto Balingka dan sebagian Lembah Malintang. Curah hujan antara 4000-4500 mm/tahun terjadi di Kec. Talamau, Gunung Tuleh dan Pasaman, yang merupakan wilayah kecamatan di Kab. Pasaman Barat yang terletak di dataran tinggi disekitar kaki Gunung Pasaman. Sedangkan curah hujan yang lebih rendah (3500-4000 mm/tahun) pada umumnya terjadi di wilayah kecamatan yang terletak dataran rendah pesisir barat Kab. Pasaman Barat

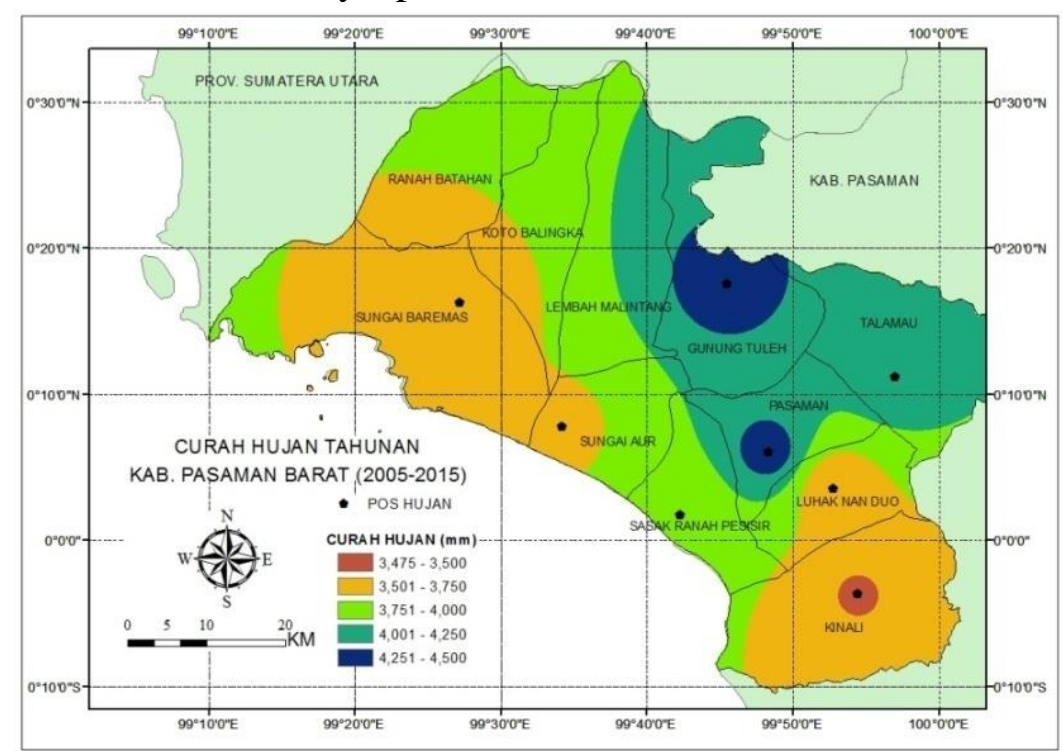

Gambar 2. Distribusi Spasial Curah Hujan di Kabupaten Pasaman Barat 
2. Pola Curah Hujan Bulanan di Kab.

\section{Pasaman Barat}

Seperti pada umumnya pola curah hujan bulanan di wilayah Sumatera Barat, pola curah hujan di wilayah Kab. Pasaman Barat juga mempunyai pola atau tipe ekuatorial, yaitu pola curah hujan dengan dua puncak hujan pada setiap tahunnya yang terjadi karena pengaruh dari pergerakan semu matahari. Untuk curah hujan di wilayah Pasaman Barat, puncak curah hujan pertama terjadi pada bulan April dan puncak yang kedua terjadi pada bulan November, seperti yang terlihat pada Gambar 2. Hal yang menarik dari pola curah hujan di Pasaman Barat adalah curah hujan yang terjadi pada bulan AgustusSeptember dimana curah hujan bulan Agustus lebih tinggi dari pada bulan
September sehingga seolah-olah bulan Agustus menjadi seperti puncak hujan yang ketiga, seperti yang terjadi di Gunung Tuleh, Talamau dan Sei Talang. Namun hal tersebut tidak terlihat untuk wilayah yang terletak di pesisir barat Pasaman Barat seperti Sei Baremas, Sasak dan Parit (Sei Aur), artinya curah hujan bulan Agustus lebih rendah dibandingkan dengan curah hujan September pada lokasi-lokasi ini.

Dari Gambar 2, juga dapat diketahui, bahwa rata-rata curah hujan bulanan terendah terjadi antara bulan Mei-Juli, dengan jumlah yang tidak kurang dari 150 mm setiap bulannya, yang artinya wilayah Pasaman Barat tidak termasuk daerah zona musim, artinya di wilayah Pasaman Barat tidak pernah mengalami musim kemarau.

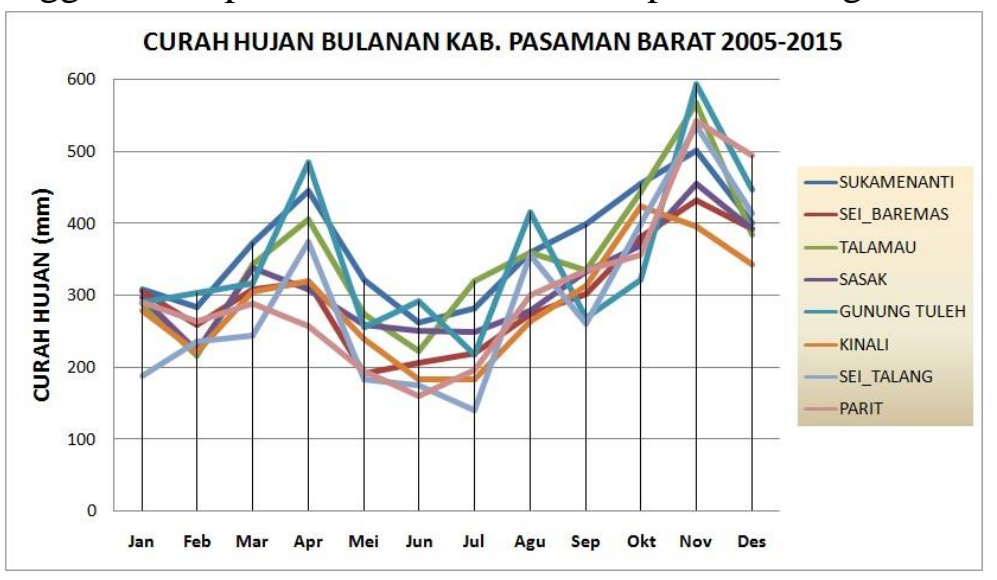

Gambar 2. Pola Curah Hujan Bulanan di Kabupaten Pasaman Barat

\section{Pola Curah Hujan Tahunan di Kab. Pasaman Barat}

Pada Gambar 3 terlihat juga adanya penurunan trend curah hujan tahunan untuk curah hujan di daerah pesisir pantai seperti terlihat jelas untuk lokasi pengamatan di Sei Baremas dan Sasak, walaupun selama lima tahun terakhir (2011-2015) pengamatan hujan di Sasak menunjukan kenaikan. Di wilayah daratan pedalaman Pasaman Barat yang diwakili oleh pos pengamatan hujan di
Sukamenanti dan Talamau, didapatkan, selain mempunyai variasi tahunan yang relative lebih tinggi, trend curah hujan tahunan di Sukamenanti mengalami penurunan pada tahun 2000-2005, hingga mencapai titik curah hujan terendah (2000 $\mathrm{mm}$ ) kemudian trend menjadi positif pada tahun 2005-2015. Lain halnya dengan curah hujan di Talamau yang cenderung stabil jumlah curah hujan antara 3000$5000 \mathrm{~mm} /$ tahunnya. 




Gambar 3. Pola Curah Hujan Tahunan di Kabupaten Pasaman Barat

Persebaran Tanaman Pangan dan Holtikultura di Wilayah Kabupaten Pasaman Barat

Pertanian adalah hal yang sangat penting artinya bagi pembangunan Pasaman Barat secara umum, khususnya di sektor Tanaman Pangan dan Perkebunan, sudah banyak komoditi Tanaman Pangan dan Perkebunan Pasaman Barat yang menjadi andalan di Propinsi Sumatera Barat contohnya : jagung, kedele, kacang hijau, kelapa sawit, kakao dan nilam. Pengembangan komoditi andalan ini digerakkan oleh Dinas Pertanian Tanaman Pangan Hortikultura dan Peternakan Kabupaten Pasaman Barat setelah diadakan pembahasan bersama (Sinergis Program) di Bappeda Pasaman Barat.

Tanaman Pangan (padi, jagung, ubi kayu, ubi jalar, kacang hijau, kacang tanah)

Jenis komoditi unggulan tanaman pangan di kabupaten Pasaman Barat ini adalah padi, jagung, kacang tanah, ubi kayu, ubi jalar, kacang Hijau serta kacang tanah.

Berikut ini akan digambarkan penyebaran sentra produksi komoditi Tanaman Pangani di Kabupaten Pasaman Barat (tahun 2011-2015) bisa dilihat pada tabel 1 dibawah ini:

Tabel. 1. Evaluasi Penyebaran Tanaman Pangan Per Kecamatan di Kabupaten Pasaman Barat periode tahun 2011-2015

\begin{tabular}{|l|l|l|l|l|l|l|l|l|}
\hline \multirow{2}{*}{ No } & \multirow{2}{*}{ Kecamatan } & Padi & Jagung & Kedelai & K.Tanah & U.Kayu & U.Jalar & K.Hijau \\
\hline 1 & $\begin{array}{l}\text { Sungai } \\
\text { Beremas }\end{array}$ & S & S & R & S & R & R & R \\
\hline 2 & $\begin{array}{l}\text { Ranah } \\
\text { Patahan }\end{array}$ & T & S & S & T & S & R & S \\
\hline 3 & Koto Balingka & R & T & T & R & S & R & R \\
\hline 4 & Sungai Aua & S & S & T & R & R & R & S \\
\hline 5 & Lembah & S & T & T & T & R & R & S \\
\hline
\end{tabular}




\begin{tabular}{|l|l|l|l|l|l|l|l|l|}
\hline & & \multicolumn{7}{|c|}{ Nama Tanaman Pangan } \\
\cline { 3 - 9 } No & Kecamatan & Padi & Jagung & Kedelai & K.Tanah & U.Kayu & U.Jalar & K.Hijau \\
\hline & Melintang & & & & & & & \\
\hline 6 & Gunung Tuleh & $\mathrm{R}$ & $\mathrm{T}$ & $\mathrm{S}$ & $\mathrm{R}$ & $\mathrm{R}$ & $\mathrm{R}$ & $\mathrm{R}$ \\
\hline 7 & Talamau & $\mathrm{T}$ & $\mathrm{T}$ & $\mathrm{T}$ & $\mathrm{S}$ & $\mathrm{T}$ & $\mathrm{T}$ & $\mathrm{T}$ \\
\hline 8 & Pasaman & $\mathrm{T}$ & $\mathrm{R}$ & $\mathrm{S}$ & $\mathrm{S}$ & $\mathrm{S}$ & $\mathrm{R}$ & $\mathrm{R}$ \\
\hline 9 & $\begin{array}{l}\text { Luhak Nan } \\
\text { Duo }\end{array}$ & $\mathrm{T}$ & $\mathrm{T}$ & $\mathrm{S}$ & $\mathrm{S}$ & $\mathrm{T}$ & $\mathrm{R}$ & $\mathrm{S}$ \\
\hline 10 & $\begin{array}{l}\text { Sasak Ranah } \\
\text { Pasisia }\end{array}$ & $\mathrm{R}$ & $\mathrm{R}$ & $\mathrm{T}$ & $\mathrm{R}$ & $\mathrm{R}$ & $\mathrm{R}$ & $\mathrm{R}$ \\
\hline 11 & Kinali & $\mathrm{S}$ & $\mathrm{S}$ & $\mathrm{S}$ & $\mathrm{S}$ & $\mathrm{T}$ & $\mathrm{R}$ & $\mathrm{S}$ \\
\hline
\end{tabular}

\section{Keterangan : $T=$ Tinggi $S=$ Sedang $R=$ Rendah}

\section{(Sumber: Pengolahan Data Penelitian 2016)}

Dari tabel 1 bisa terlihat bahwa tanaman kacang tanah produktifitasnya juga tetap bervariasi di setiap kecamatannya berkisar dari 1.43 ton/ha di Kecamatan Sasak Ranah Pesisir, dan mencapai 1.66 ton/ha untuk Kecamatan Lembah Melintang. Rata-rata produktifitas tanaman kacang tanah pada 5 tahun terakhir untuk Kabupaten Pasaman Barat adalah 1.54 ton/ha Produktifitas tertinggi berada pada Kecamatan Ranah Patahan,dan L. Malintangi. Peringkat sedang berada pada Kecamatan S. Beremas, Talamau, Pasaman, Luhak Nan Duo, dan Kinali. Kategori rendah berada pada Kecamatan Koto Balingka, S. Aua, G. Tuleh dan Sasak. Produktifitas tanaman pangan lainnya bisa dilihat pada tabel 1 diatas.

Daerah Talamau menjadi daerah yang unggul untuk produktifitas tanaman pangan di Kabupaten Pasaman Barat. Talamau terletak di sekitar wilayah pegunungan dengan curah hujan yang stabil. Penurunan trend curah hujan tahunan untuk curah hujan di daerah pesisir pantai seperti terlihat jelas untuk lokasi pengamatan di Sei Baremas dan Sasak, walaupun selama lima tahun terakhir (2011-2015) pengamatan hujan di

Sasak menunjukan kenaikan. Di wilayah daratan pedalaman Pasaman Barat yang diwakili oleh pos pengamatan hujan di Sukamenanti dan Talamau, didapatkan, selain mempunyai variasi tahunan yang relative lebih tinggi, trend curah hujan tahunan di Sukamenanti mengalami penurunan pada tahun 2000-2005, hingga mencapai titik curah hujan terendah (2000 $\mathrm{mm}$ ) kemudian trend menjadi positif pada tahun 2005-2015. Lain halnya dengan curah hujan di Talamau yang cenderung stabil jumlah curah hujan antara 3000$5000 \mathrm{~mm} /$ tahunnya.

Secara keseluruhan di Pasaman Barat, maka daerah yang unggul dan termasuk peringkat tertinggi untuk tanman pangan adalah Kecamatan Talamau, Peringkat sedang pada Kecamatan Ranah Patahan, Lembah Melintang, Luhak Nan Duo, dan Kinali, sedangkan peringkat rendah diraih oleh Kecamatan Sungai Beremas, Sungai Aua, Gunung Tuleh, Pasaman, Sasak, dan Koto Balingka.

Tanaman Holtikultura kategori Buahbuahan (pisang, alpokat, rambutan,salak, duku, durian, nanas dII)

Jenis komoditi unggulan tanaman buah-buahan di kabupaten Pasaman Barat 
ini adalah pisang, alpokat, rambutan,salak, duku, durian, nanas dan lainnya.

Berikut ini akan digambarkan penyebaran sentra produksi komoditi pisang di Kabupaten Pasaman Barat (tahun 2011-2015) seperti gambar 10 di bawah ini:

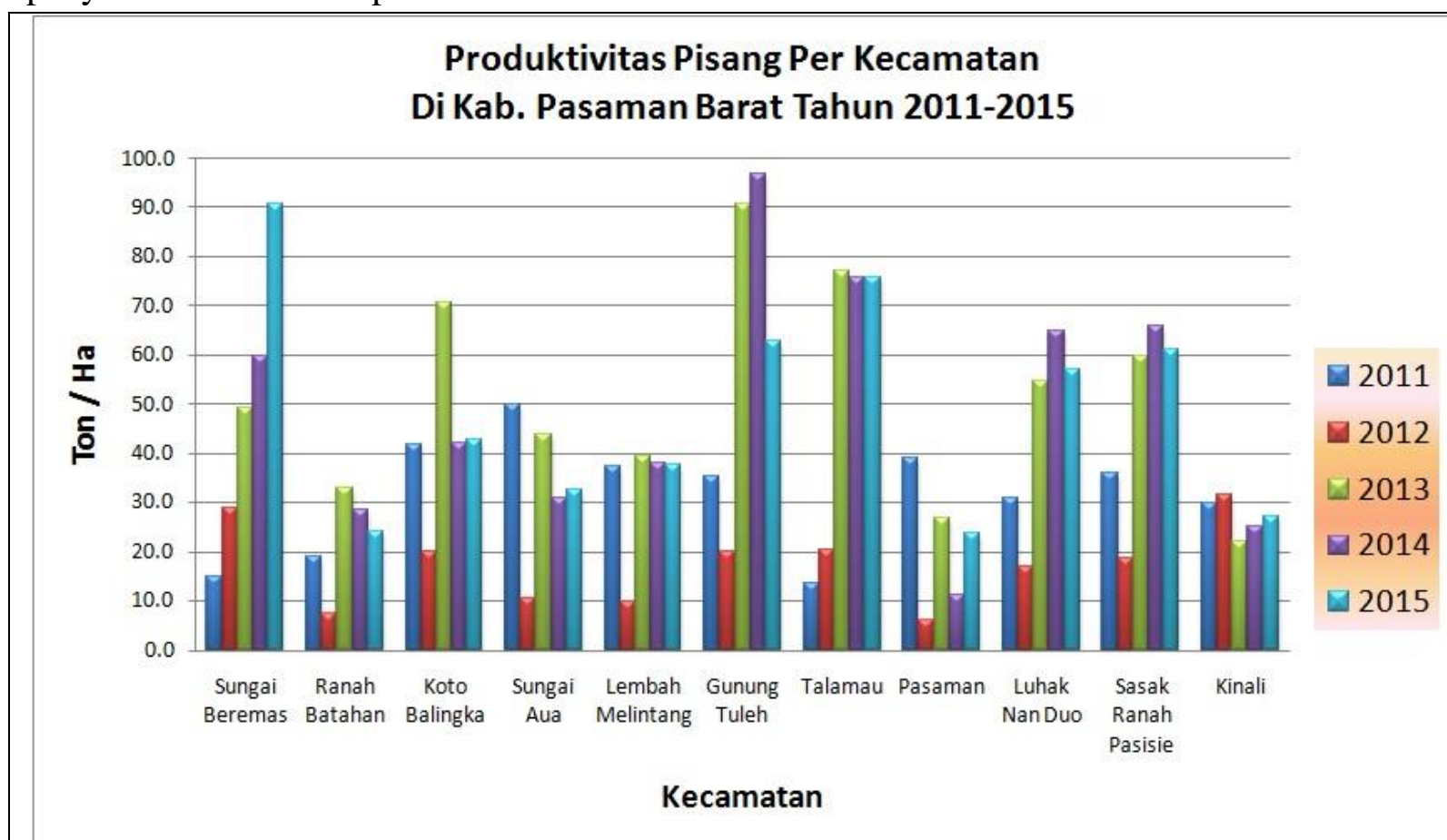

Gambar 10. Produktifitas Pisang Per Kecamatan di Kabupaten Pasaman Barat (2011-2015).

Dari gambar 10, bisa kita lihat bahwa tanaman pisang tumbuh dengan produktifitasnya bervariasi untuk masingmasing kecamatan di setiap tahunnya. Namun rata-rata produktifitas untuk 5 tahun terakhir (2011-2015) berkisar antara 21.52 ton/ha sampai 61.20 ton/ha. Produktifitas yang rendah terdapat pada Kecamatan Pasaman, Ranah Batahan, Sungai Aua, Lembah Melintang, dan Kinali, untuk kategori sedang terdapat pada Kecamatan Koto Balingka, Luhak
Nan Duo, dan Sasak ranah Pasisie. Sedangkan daerah yang paling tinggi produktifitas tanaman pisangnya adalah Kecamatan Gunung Tuleh dan Talamau. Rata-rata produktifitas tanaman pisang pada 5 tahun terakhir untuk Kabupaten Pasaman Barat adalah 39.68 ton/ha.

Berikut ini akan digambarkan penyebaran sentra produksi komoditi Tanaman Pangan di Kabupaten Pasaman Barat (tahun 2011-2015) bisa dilihat pada tabel 2 dibawah ini:

Tabel 2. Evaluasi Penyebaran Produktifitas Tanaman Buah di Pasaman Barat periode tahun 2011-2015

\begin{tabular}{|l|l|l|l|l|l|l|l|l|l|l|l|l|}
\hline No & \multirow{2}{*}{} & \multicolumn{10}{|c|}{ Nama Buah } \\
\cline { 3 - 18 } & & Pisang & Pokat & Rambutan & Salak & J.Biji & duku & duren & manga & Nenas & \multirow{2}{*}{ jeruk } & pepaya \\
\hline 1 & S.Beremas & S & T & T & - & T & T & T & S & - & S & S \\
\hline 2 & R. Patahan & R & R & R & R & R & R & T & S & R & R & R \\
\hline 3 & K. Balingka & S & S & S & R & R & S & R & R & R & R & R \\
\hline 4 & S. Aua & R & R & R & R & R & R & S & R & T & R & S \\
\hline 5 & L. & R & R & R & R & S & - & R & R & T & S & R \\
\hline
\end{tabular}




\begin{tabular}{|c|c|c|c|c|c|c|c|c|c|c|c|c|}
\hline \multirow[t]{2}{*}{ No } & \multirow[t]{2}{*}{ Kecamatan } & \multicolumn{11}{|c|}{ Nama Buah } \\
\hline & & Pisang & Pokat & Rambutan & Salak & J.Biji & duku & duren & mangga & Nenas & jeruk & pepaya \\
\hline & Melintang & & & & & & & & & & & \\
\hline 6 & G.Tuleh & $\mathrm{T}$ & $S$ & $\mathrm{~S}$ & $\mathrm{~T}$ & $S$ & $\mathrm{R}$ & $S$ & $\mathrm{R}$ & $\mathrm{T}$ & $\mathrm{T}$ & $\mathrm{R}$ \\
\hline 7 & Talamau & $\mathrm{T}$ & $\mathrm{S}$ & $\mathrm{S}$ & $\mathrm{S}$ & $\mathrm{R}$ & - & $\mathrm{T}$ & $\mathrm{T}$ & $\mathrm{T}$ & $\mathrm{S}$ & $\mathrm{R}$ \\
\hline 8 & Pasaman & $\mathrm{R}$ & $\mathrm{R}$ & $\mathrm{R}$ & $\mathrm{R}$ & $\mathrm{R}$ & $\mathrm{R}$ & $\mathrm{R}$ & $\mathrm{R}$ & $\mathrm{R}$ & $\mathrm{S}$ & $\mathrm{R}$ \\
\hline 9 & L. Nan Duo & $S$ & $\mathrm{R}$ & $\mathrm{R}$ & $\mathrm{R}$ & $\mathrm{R}$ & $\mathrm{R}$ & $\mathrm{R}$ & $\mathrm{R}$ & $S$ & $\mathrm{R}$ & $\mathrm{T}$ \\
\hline 10 & $\begin{array}{l}\text { Sasak } \\
\text { R.Pasisi }\end{array}$ & S & $\mathrm{T}$ & $\mathrm{R}$ & - & S & - & S & $\mathrm{T}$ & $\mathrm{R}$ & $\mathrm{R}$ & $\mathrm{R}$ \\
\hline 11 & Kinali & $\mathrm{R}$ & $\mathrm{R}$ & $\mathrm{R}$ & - & $\mathrm{R}$ & - & $\mathrm{R}$ & $\mathrm{R}$ & - & $\mathrm{R}$ & $\mathrm{R}$ \\
\hline
\end{tabular}

Keterangan $\mathrm{T}=$ Tinggi $\mathrm{S}=$ Sedang $\mathrm{R}=$ Rendah

Sumber : Pengolahan Data Penelitian 2017

Secara keseluruhan untuk Kabupaten

Pasaman Barat, maka Kecamatan yang termasuk peringkat tinggi untuk produktifitas tanaman buah adalah Kecamatan Sungai Beremas, Gunung Tuleh, dan Talamau. Peringkat sedang pada Kecamatan Ranah Patahan, Koto Balingka, Sungai Aua, Lembah Melintang, Pasaman, Luhak Nan Duo, dan Sasak. Daerah yang paling rendah adalah Kecamatan Kinali. Wilayah yang produktifitas paling bagus untuk tanaman buah ternyata wilayah dekat pegunungan yang curah hujannya tinggi. Selain kondisi daerah seperti tanah, air dan ketinggian tempat, faktor lain yang ikut mendukung berhasilnya produksi suatu jenis tanaman adalah pengolahan lahan, budi daya tanam dan pemeliharaannya.

\section{SIMPULAN}

Dari hasil penelitian dapat diambil beberapa kesimpulan diantaranya adalah:

1. Selama periode tahun 2000-2015, curah hujan di wilayah pesisir pantai mempunyai variasi tahunan yang relative kecil di bandingkan dengan

curah hujan tahunan di wilayah daratan pedalaman Pasaman Barat. Fenomena global ENSO (El Nino dan La Nina) tidak secara signifikan mempengaruhi variabilitas curah hujan bulanan di wilayah Kab. Pasaman Barat, baik untuk di wilayah peisisir pantai maupun wilayah daratan pedalamannya

2. Kecamatan yang tertinggi untuk produktifitas tanaman pangan adalah Kecamatan Talamau, Peringkat sedang pada Kecamatan Ranah Patahan, Lembah Melintang, Luhak Nan Duo, dan Kinali, sedangkan peringkat rendah diraih oleh Kecamatan Sungai Beremas, Sungai Aua, Gunung Tuleh, Pasaman, Sasak, dan Koto Balingka.

Kecamatan yang tertinggi untuk produktifitas tanaman buahnya adalah Kecamatan Sungai Beremas, Gunung Tuleh, dan Talamau. Peringkat sedang pada Kecamatan Ranah Patahan, Koto Balingka, Sungai Aua, Lembah Melintang, Pasaman, Luhak Nan Duo, dan Sasak. Daerah yang paling rendah adalah Kecamatan Kinali.

\section{DAFTAR PUSTAKA}

Guntoro, Suprio. 2011. Saatnya Menerapkan Pertanian Tekno-ekologis. PT Agromedia Pustaka. Jakarta

Heddy, Suwasono, 2010. Agroekosistim Permasalahan Lingkungan Pertanian Bagian Pertama. PT Rajawali Press. Jakarta 
Intergovernmental Panel on Climate Change (IPCC). 2007. A report of the Working Group of the Intergovernmental Panel on Climate Change Summary for Policymakers, Geneva, Intergovernmental Panel on Climate Change.

Nahas, C.N. dan B. Setiawan, 2010. Penentuan Radiative Forcing Dan Annual Greenhouse Gas Index (Aggi) Dari Karbon Dioksida, Metana, Dan Nitrous Oksida Hasil Pengukuran Di Bukit Kototabang. Buletin Megasains, Vol.4

Nugroho, S., Heron, T., dan Eddy, S. 2009. Trends Curah Hujan Ekstrim di Kota Padang, 1970-2008, Buletin Megasains, Vol.4.

Nugroho, S. 2011. Kajian Simulasi Adaptasi Terhadap Tingkat Kenyamanan Termal Akibat Perubahan Iklim Global Di Kota Padang, Karya Tulis Ilmiah Diklat Fungsional Peneliti-LIPI, Tahun 2010. Jurnal Widyariset, Vol.14 Thn 2011, Pusbindiklat-LIPI.

Pudja, I.P. dan Suhardi, B. 2010. Fenomena Perubahan Iklim di Indonesia. Badan Meteorologi Klimatologi dan Geofisika, Jakarta.Sastrapradja, S.D dan elizabeth A.W. 2010. Keanekaragaman Hayati Pertanian Menjamin Kedaulatan Pangan. LIPI Press. Jakarta.

Tjasyono, Bayong. 2009. Meteorologi Indonesia I Karakteristik dan Sirkulasi Atmosfir. BMKG. Jakarta.

Tjasyono, Bayong. 2009. Meteorologi Indonesia II Awan dan Hujan Monsun. BMKG. Jakarta.

Zhang, X and Yang, F. 2004. User Manual RclimDex (1.0). Climate Research Branch, Enviroment Canada, Downsview, Ontario, Canada.

Penentuan Radiative Forcing Dan Annual Greenhouse Gas Index (Aggi) Dari Karbon Dioksida,zMetana, Dan Nitrous Oksida Hasil Pengukuran Di Bukit Kototabang 